\title{
Chained Bodies and Monuments of Hierarchy in Hungarian Performance Art
}

\author{
Katalin Cseh 1,2 \\ ${ }^{1}$ Graduate School of East and Southeast European Studies, Ludwig Maxilians University Munich, Munich, \\ Germany \\ ${ }^{2}$ Department of Theatre, Film and Media Studies, University of Vienna, Vienna, Austria \\ Email: Katalin.Cseh@Imu.de
}

Received 15 August 2014; revised 17 September 2014; accepted 25 October 2014

Copyright (C) 2014 by author and Scientific Research Publishing Inc.

This work is licensed under the Creative Commons Attribution International License (CC BY).

http://creativecommons.org/licenses/by/4.0/

c) (i) Open Access

\begin{abstract}
Hungary's history was as troubled as Eric Hobsbawm stated Europe's past in Age of Extremes. The Short Twentieth Century, 1914-1991. Dictatorships followed each another right from the end of WWI until the system change in 1989, but among all the authoritarian regimes socialism existed longest. After the thawing atmosphere of the second half in the 1960s, critical tone was articulated in the Neo-Avant-Garde's "second public sphere". A form of criticism against any kind of hierarchical repression arose from performative and intermedial artworks and still didn't disappear even in postmodern times long after the fall of the wall. The paper will focus on three-dimension of hierarchical bondage: being chained through the other, trough the authorities and through history. All artists' works (that of El Kazovszkij, Tamás St. Auby and Little Warsaw) are meant to show inner relations between the body, its representation, authoritarian practice of control respectively performance and intermedia art.
\end{abstract}

\section{Keywords}

Hungary, Performance Art, El Kazovszkij, Tamás St. Auby, Little Warsaw

The expression of "hierarchy" in the title of my talk doesn't necessarily refer to the communist dictatorship as such, but to any kind of order that the chosen artists relate their work to. To put it another way: the examples I will talk about represent no rebellion against hierarchy, but an indirect criticism on social, political, cultural and even deeply personal issues. The Hungarian Neo-Avant-Garde wasn't a direct opposition against the ruling system, but a sensitive pool of innovative ideas, which mirrored events in a creative manner. The strategy of reflection in the experimental art scene (even beyond the symbolic turn of 1989) could possibly be equated with the understanding of a "second public sphere" or "parallel culture". 
On one hand this "second public sphere" was coined (amongst others) by Hungarian intellectuals mainly in the 1970s and 1980s, who designated it as a potential of autonomous action (Elemér Hankiss) and as an extension of the given order (Konrád, 1980). The "second public sphere" is also the emblematic place, where one can break through the publicity of the official regime, where autonomous spaces appear or are protected, where methods of a counterculture are developed to make a difference in opinion visible (Behrends, 2010).

On the other hand the notion of the "second public sphere" has a dimension that reaches beyond the socialist era and its relation to dissent. In the optimistic understanding of Piotrowski (2012) a dialogue between the civil society and the critical avant-garde could be established after 1989. This agonistic concept of democracy with a basis for fruitful conflict, inspired by Mouffe (2007) still seems to be an utopist idea in contemporary Central and Eastern Europe.

Experimental art projects after the system turn often cross the border of the historically connoted "second public sphere": they occupy public spaces, which haven't been yet recovered from official representational mechanism and they are in a way connected to Hannah Arendt's "space of appearance", because they focus on social, political and-as mentioned before-personal criticism. Maybe we should, but we can't completely ban the political moment of the transformed "second public sphere" in Hungary: the coded or direct articulation of opinion and the display of the own position in different public spheres (Cseh, 2014). The main idea is that there's a common moment in the "second public sphere" during as well as after socialism: restrictions and boundaries are still present-they just change shape.

To explain and display Hungarian artist's handling of diverse hierarchical ties, I will offer the approach of the mental image of being chained. To demonstrate the performative reaction on personal, social, political and cultural phenomena in Hungary before but also after 1989 I'd like to introduce three categories of being chained through the other, through authorities and through history. In the framework of the first category, firstly I will examine the Dshan Panoptic - project of El Kazovszkij; secondly I will concentrate on different action pieces of Tamás Szentjóby who expressed his criticism of repression in many ways; and thirdly I'd like to address the counter opinion to a dominant historiography in works manufactured by the artist duo Little Warsaw.

Both Kazovszkij and Szentjóby belong to a critical and nonconformist artist generation that started working in the late 1960s. Constant transformation in the cultural policy (from liberal to hard-liner) challenged the approach of this generation - they had adapt and react quickly and efficiently to "survive" (Tumbas, 2012). A group of young artists were active with a self-confident attitude, who didn’t fear public statements (Sasvári, 2003). Several artists of the Hungarian Neo-Avant-Garde scene were-compared to other art circles in Central and Eastern Europe-highly politicized. The call for autonomy from the late 1960s was clearly visible (Piotrowski, 2007). Although their intention was extremely dissimilar, Kazovszkij and Szentjóby were internationally recognized artists and defenders of an "unchained" art—even during and after communism. Little Warsaw belongs to the post-socialist generation who coins the notion of history as a continuum and is therefore seeking for connections with "past" artists and artworks. A reenactment-cooperation of Little Warsaw and Szentjóby in 2005 is well-known. While looking at the works and activity of these artists a critical "recycling" of the historical avant-garde and modernistic positions is apparent: the post-avant-garde (Šuvaković, 2009) of late socialism and a specific post-modernism of post-communism.

The Russian-born El Kazovszkij's Dshan Panoptic was a series of performance-installations with human statues realized between 1977 and 2001. As the subtitle of the work shows, it was a Play about Objectification (Földényi). The relationship of lovers is depicted in a mythical and extremely artificial environment, with an accentuation of love as a sphere of destruction and death that goes hand in hand with harmony, happiness (Földényi). Through the love of another person one is chained and becomes an object and ruler in the intimate situation. Because the work of Kazovszkij is an immersive art piece and tries to distinguish the ultimate view of a panopticon, the spectator becomes a part of the complex environment (Földényi) and observes the sculptural figures. As László Földényi F. is analyzing the Dshan panoptic and the involvement of the recipient, he uses the term "trap" in which he refers to helplessness of the individual. Contrary to a Foucaultian understanding of a panopticon (Deleuze, 1987) the emphasis is on the cliff-hanging relationship between a ruling man and an objectified woman.

Each part of the Dshan panoptic has a given structure and dramaturgy. The play can include 3 to 17 figures (Földényi) that represent the emotional exchanges between an active man (subject) and a passive woman (object) (Kazovszkij, 1978). The dramaturgy contains the following parts, in a circle that can be repeated endlessly (and this repetition is essential for demonstrating the paralyzed individual): fetish creation, ceremony, experiment and 
defeat of creating relationships, destruction (Kazovszkij, 1978).

The Dshan panoptic has a distinct performative character, not only because the artist worked since 1981 as a stage and costume designer in Györ (Kristóf, 1987). Földényi draws our attention to the theatre concept of Antonin Artaud: "For Artaud, the theater [sic!] is the best way to lead people to the outermost limits of experience. The purpose of his ideal theater [sic!] is to destroy boundaries and to confront people with the naked truth" (Földényi, 2003). Artaud's stage is honestly cruel and questions the traditional theatre separation (stage/auditorium). The latter consideration and a disclosure of boundaries is true for El Kazovszkij's work as well, but the methods, tools and intentions are contrarian.

The source of Kazovszkij's inspiration is her own sexual and emotional unconsciousness and doubts, which she extends to a simulated, magical-tragic fiction: "Each passer-by until he/she lives is a compulsory work and monument of his/her life. He/she is a monument of him/herself, and also a monument of others. The monument protection is valid for everyone" (Földényi). The Dshan Panoptic is theatrical because of a majority of statical poses (stage design) and because of its directness towards the individual and real life (happening, environment). Kazovszkij's work displays one essential feature in the art of the "second public sphere" too: the inner exile of an artist where the idea of the Dshan Panoptic has its origin. Its very personal theme doesn't change with time, it slightly shifts from experiment to institutionalization as an exotic piece of the Hungarian art scene.

The provocative artworks of Tamás Szentjóby (inspired amongst others by conceptualism and action art) lead us to the second category of being chained through authorities. Unlike Kazovszkij, Szentjóby is interested in broader social and political issues and leaves the personal access aside, although both artists were interested to develop certain "systems"/"frameworks" within their ideas can be embodied. Since the late 1960s he has also processed the boundaries of authoritarian order-not only those of socialism (e.g. Portable trench for three persons (1979?); Exclusion excersice. Autotherapy to prevent punishment (1972)). Because he belonged to those artists whose works and actions were partly based on political radicalism (or could be interpreted as such) (Fowkes, 2008), he could only position himself in the "second public sphere".

A monumental gesture of Szentjóby to uncouple the chains of Hungary's socialist authority was The Statue of Liberty's Soul (1992). The artist covered the Statue of Liberty — erected as a memorial for the Soviet "release" of the country in 1945-with a huge white drapery for three days on the anniversary of the so called "Farewell", when the last Soviet armed troupes left the country.

The event was a clear interruption and disturbance in the well-known cityscape of Budapest that potentially led to a number of misinterpretations (Boros, 1992). Boros (1992) mentions that Szentjóby's work is not surpassable because it tried to capture the disembodied soul of the symbolical place and to call up the "soul of freedom".

Szentjóby (2002) himself considers The Statue of Liberty's Soul as an intention of transition. He writes: “The transformation happened in the last moment: in the first moment of the system turn. There will never be a similar moment again!" He may refer to the moment where the gap between the "first" and the "second public sphere" was not so wide, where no rigid control was established yet. This gap allowed the artist to interfere with the boundaries created by authorities. The negative feedback as well as the necessary advertisement that were attached to the project show how one can't just state that Szentjóby's event marks the end of a repressed era and the beginning of a democratic calculation of times without ruling forces. The changes in the political order didn't mean an immediate turn in the socio-cultural attitude. And this is the reason why a "second public sphere" and its critical attitude were still needed.

The Statue of Liberty's Soul wasn't only an installation but a multimedia event involving video, design, photographic documentation and interpretation (Bartoš). The perception and assessment of the transformed statue couldn't be detached from the different media that surrounded the artwork. Even a demonstrative performance occurred that was closely linked not only to Szenjóby's installation but also to his personal history as the organiser and participant of umpteen happenings: the daughter of the statue's model and a few friends dressed up like ghosts and were demonstrating against the abuse of the national monument (Boros, 1992).

To sum it up: The Statue of Liberty's Soul is an example of how to unchain a community from repression and authoritarian past and present. On the one hand it is an attempt to introduce a new beginning, on the other hand it draws our attention to the fact that new or still existent control mechanisms will rule again.

Although this last example could show how the artistic contact with being chained through history works, I will add here some final thoughts on the Hungarian artist duo Little Warsaw (András Gálik and Bálint Havas). Their work is interesting because they have other roots than Kazovszkij or Szentjóby. Little Warsaw’s approach 
is clearly post-socialist, but through their underground activity it forms a special occurrence of a $21^{\text {st }}$ century's "second public sphere".

As The Statue of Liberty's Soul illustrated, re-purposing communist monuments is a sensitive issue in Central and Eastern Europe. Critical and (self-)reflexive treatments of ideology-burdened historical material are rare. The Hungarian Memento Park is rather a decayed example of storing relicts of social realism without any commentary at a "neutral" place and using it as a tourist attraction-even an educational "theme park". The alienation from and marginalisation of history that was "our" own too, is likely problematic.

Little Warsaw's approach to history-and not only to the communist past of Central and Eastern Europe-is more challenging. They deal with given material in a precise and purposeful way and demonstrate that-as in postmodern historiography - the past is not a closed phenomenon but a process and that interpretation is legitimate as well as essential to creative experiment. Although we often try to escape the claws of history we are in the midst of it—chained by its consequences and different memories. And this is one principal message of Little Warsaw's works.

I will examine a "manipulated" art piece, namely The Body of Nefretiti (2003), which was conceptualised for the Hungarian pavilion of the Venice Biennale in 2004. The aim of the project was to design a body for the famous Nefretiti portrait. The enterprise was courageous because Nefretiti is an icon over interpreted with a multiplicity of replica (Szentpéteri, 2003). The Egyptian queen is also an "art of our visual culture” (Petrányi). From the point of view of the artists the "[...] public sculpture is especially important for them as something that its message and appearance seeks to be "communal", the vehicle of ideas and aesthetic values whose tradition greatly relies on the notion of consensus, agreement on aesthetics and content.” (Petrányi) The created torso of Nefretiti became an autonomous but fragmented entity, which raised the question of identity (Petrányi).

The Body of Nefretiti is performative in two respects: one moment of culmination in the torso's history when the body and the head of Nefretitii become united - even Zsolt Petrányi calls it a "symbolic "performance". The second aspect is the media scandal and bilateral cultural conflict that Little Warsaw's project causes in Egyptian circles and which Mestyán (2006) fabulously summarizes as the Nefretiti paradigm. The Body of Nefretiti stands for a creative artistic approach that challenges an authoritarian understanding of history and determines a form of artistic autonomy and freedom to intervene. This particular statue does not deal with history during communism per se, but offers a wider insight into history as a postmodern discourse. In some other works Little Warsaw plays with the de-contextualization of socialist monuments and symbols with the same intention as in the case of The Body of Nefretiti: to capture the binding role of history and to make its chains transparent.

I have outlined how the categories of being chained in the Hungarian experimental art scene react to distinct manifestations of hierarchy. It seems that a fight for autonomous and uncensored art is a significant motif during as well as beyond socialism. Although episodes of the Hungarian "dictatorship-light" allowed certain freedom through the official cultural policy, the progressive art scene mainly developed in a parallel culture. After 1989 the chance for interference between the "second" and the "first public sphere" grew rapidly and the hope that there might not be a need for an underground was constantly present. But (politically and socially) critical or even provocative works from different artist generations target at lacks in the public awareness about actual, historical and personal hierarchies.

The roots of developing creative interactions and reactions lie (in the case of the consulted examples) in the common history and/or practice of a "second public sphere", which still exists, although it has been radically transformed.

In this paper I investigated the historical and current relation of a "first" and "second public sphere" in Hungary's avant-garde art through the criticism of different forms of hierarchies. The "first public sphere" is understood as a phenomenon of official, accepted and controlled representation rooted in late socialism, whereas "the second public sphere" is constituted as a (paradoxical) parallel culture, which makes the expression of a critical public discourse possible. The image of "being chained" represents an artistic reaction to impulses of the "first public sphere" based on the "second".

\section{Note}

The original version of this paper was first presented at the annual conference of the College Art Association on February 15, 2014 in Chicago, USA. It was part of the session Performance Art in Central and Eastern Europe chaired by Amy Bryzgel and Pavlina Morganova—many thanks to both of them for accepting my presentation's draft and giving me advise how to improve it. I am also very grateful to Scott Kushner for revising this piece 
and for not becoming tired in encouraging me to sharpen my thoughts. And last but not least: I appreciate the support of Júlia Klaniczay, György Galántai (directors of the Artpool Art Research Center) and Dóra Halasi (archivist at Artpool) who made the intense research phase possible while preparing this article. Without the financial help of the Graduate School for East and Southeast European Studies at the Ludwig-Maxilians-University Munich the publication of the paper wouldn't have been possible—-thank you for that.

\section{References}

Behrends, J. C. (2010). Repräsentation und Mobilisierung: Eine Skizze zur Geschichte der Öffentlichkeit in der Sowjetunion und in Osteuropa (1917-1991). In U. Daniel, \& A. Schildt (Eds.), Massenmedien im Europa des 20. Jahrhunderts (pp. 229-254). Köln/Weimar/Wien: Böhlau.

Boros, G. (1992). A Gellért-Hegy Fantomja. ÉS, July 10.

Cseh, K. (2014). Rebellische (Spiel) Räume und Underground-Netzwerke. Die “zweite Öffentlichkeit” der ungarischen Avantgarde. Ph.D. Thesis (Manuscript), Munich: Ludwog-Maximilians-University Munich.

Deleuze, G. (1987). Foucault. Frankfurt a.M.: Suhrkamp.

Földényi, F. L. (2003). The Aesthetic of Celebration. In El Kazovszkij. Budapest: Mücsarnok.

Földényi, F. L. A szerelem mitosza: El Kazovszkij Dzsan-panoptikuma. Manuscript.

Fowkes, M., \& Fowkes, R. (Eds.) (2008). Revolution I Love You: 1968 in Art, Politics and Philosophy. Forradalom Szeretlek. 1968 a művészeben, a politikában és a filozófiában. Manchester/Thessaloniki/Budapest: MIRIAD/Metropolitan University with CACT Thessaloniki/Trafó-House of Contemporary Arts.

Kazovszkij, E. (1978). Dzsan-panoptikum magyarázó szöveggel és képekkel. Mozgó Világ, 5, 34-43.

Konrád, Gy. (1980). Az autonómia kísértése: Kelet-nyugati utigondolatok 1977-1979. Paris: Magyar Füzetek Könyvei 2.

Kristóf, A. (1987). Siker és ifjúság (El Kazovszkij). Az elveszett nyelv. Magyar Nemzet, February 7, 4.

Mestyán, À. (2006). A Nefretiti-Paradigma. Holmi, 8, 1075-1087.

Mouffe, C. (2007). Über das Politische. Wider die kosmopolitische Illusion. Frankfurt: Suhrkamp.

Pertu No.7. Peter, B., \& St.Auby, T. Galéria Umenia Nové Zámky. Művészeti Galéria Érsekújvár.

Petrányi, Z. The Body of Nefreteti. Exhibition Catalogue.

Piotrowski, P. (2007). From the Politics of Autonomy to the Autonomy of Politics. Art History \& Criticism. Art and Politics: Case-Studies from Eastern Europe, 3, 18-24.

Piotrowski, P. (2012). Art and Democracy in Post-Communist Europe. London: Reaction Books.

Sasvári, E. (2003). A balatonboglári kápolnatárlatok kultúrpolitikai háttere. In J. Klaniczay, \& E. Sasvári (Eds.), Törvénytelen avantgárd. Galántai György balatonboglári kápolna müterme 1970-1973 (pp. 9-38). Budapest: Artpool-Balassi.

St. Auby, T. (2002). A Szabadság Lelkének Szobra 1992. W. A Dunánál, July, 5-6.

Šuvaković, M. (2009). Remembering the Art of Communism. Analysis of Contradictions: Approaches and Transgressions. Socialist Eastern Europe, 23, 15-24. http://dx.doi.org/10.1080/09528820902786594

Szentpéteri, M. (2003). Varsó Velencében. Havas Bálint és Gálik András képzőművész. Magyar Narancs, May 22, 38-39.

Tumbas, J. (2012). International Hungary! György Galántai’s Networking Strategies. ARTMargins, 1, 87-115.

http://dx.doi.org/10.1162/ARTM_a_00020 
Scientific Research Publishing (SCIRP) is one of the largest Open Access journal publishers. It is currently publishing more than 200 open access, online, peer-reviewed journals covering a wide range of academic disciplines. SCIRP serves the worldwide academic communities and contributes to the progress and application of science with its publication.

Other selected journals from SCIRP are listed as below. Submit your manuscript to us via either submit@scirp.org or Online Submission Portal.
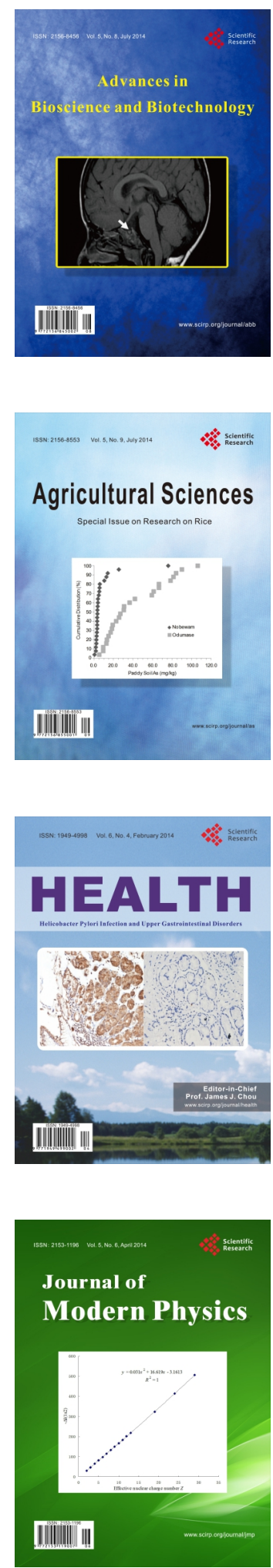
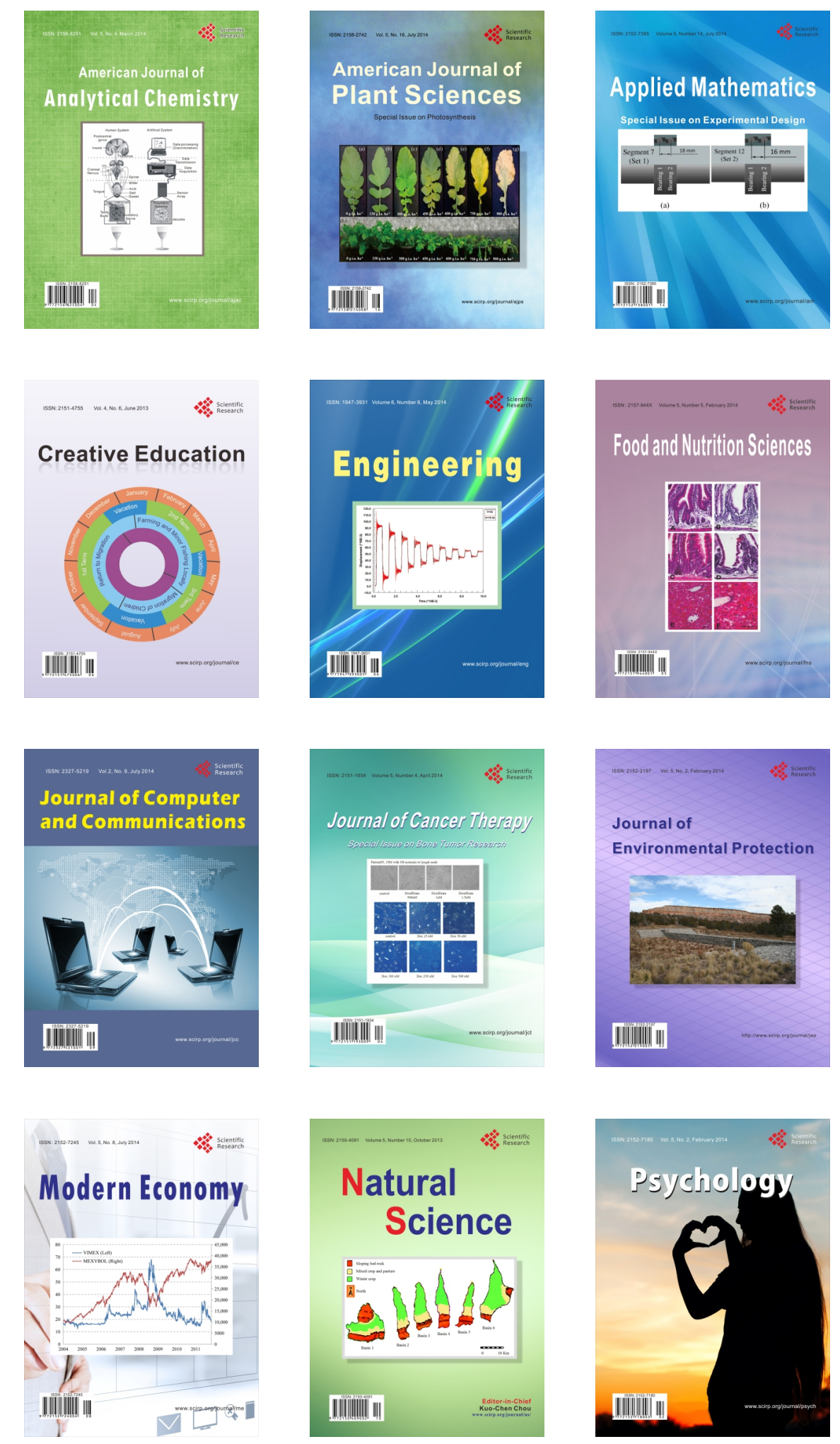